The diversity of life 
FOUNDATIONS OF BIOLOGY

General editor L. M. J. Kramer

A major advanced biology course

for schools and colleges

Books in the series are:

The diversity of life

The cell concept

Heredity, development and evolution

Metabolism, movement and control

Man and the ecosystem 


\section{The diversity of life}

C. Mary Jenking, B.Sc

Head of Biology department, Maynard School, Exeter

Ann Boyce, B.Sc

Biology department, Maynard School, Exeter

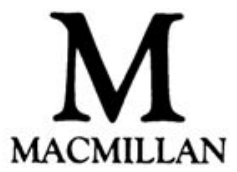


(C) C. M. Jenking and A. Boyce 1979

All rights reserved. No reproduction, copy or transmission of this publication may be made without written permission.

No paragraph of this publication may be reproduced, copied or transmitted save with written permission or in accordance with the provisions of the Copyright Act 1956 (as amended), or under the terms of any licence permitting limited copying issued by the Copyright Licensing Agency, 33-4 Alfred Place, London WCIE DP.

Any person who does any unauthorised act in relation to this publication may be liable to criminal prosecution and civil claims for damages.

First published 1979

Reprinted 1981, 1982, 1983, 1984, 1985, 1987

Published by

MAGMILLAN EDUCATION LTD

Houndmills, Basingstoke, Hampshire RG21 2XS

and London

Companies and representatives

throughout the world

British Library Cataloguing in Publication Data

Jenking, $\mathbf{C} \mathbf{M}$

The diversity of life, - (Foundations of biology).

1. Biology

$\begin{array}{lll}\text { I. Title II. Boyce, A } & \text { III. Series }\end{array}$

$574 \quad$ QH308.7

ISBN 978-0-333-24193-6 ISBN 978-1-349-03987-6 (eBook)

DOI 10.1007/978-1-349-03987-6 


\section{Contents}

Preface vii

I Organisation and complexity I

2 Naming and classifying organisms Io

3 Phylum Protozoa I9

4 Phylum Algae 28

5 Phylum Fungi 36

6 Phylum Coelenterata 48

7 Phylum Platyhelminthes 55

8 Phylum Nematoda 65

9 Phylum Annelida 68

Io Phylum Arthropoda 73

I I Phylum Mollusca Ioo

12 Phylum Echinodermata 107

I 3 Phylum Bryophyta I I I

I4 Phylum Pteridophyta I 9

I5 Phylum Spermatophyta-introduction 129

I6 Class Gymnospermae $\quad{ }^{32}$

17 Class Angiospermae ${ }_{138}$

I8 Phylum Chordata $\quad{ }^{6} 3$

I9 Life cycles $\quad$ I94

Suggestions for further reading $\quad$ I96

Index $\quad 198$ 


\section{Preface}

Foundations of biology aims to provide a complete pre-university course in biological science. Accordingly, the work is covered in a few handy volumes, not in a single bulky one or numerous monographs. The questions at the ends of the chapters are to test comprehension of the material covered in the chapters and their contents are not necessarily similar to those set in biological examinations which often require knowledge in several branches of biology if they are to be answered properly. Suggestions are provided for further reading.

The course consists of five books written by experienced teachers with special knowledge of biological science, who believe through their experience that fresh approaches to teaching biology are desirable at pre-university level. The books in the series are:

The diversity of life

The cell concept

Heredity, development and evolution

Metabolism, movement and control

Man and the ecosystem.

Biologists will realise the difficulty of subdividing the course into a number of books and opinions will undoubtedly differ on how it should best be done. One difficulty is that a number of topics are based upon knowledge of others, so that if each book is to be helpful some overlap must occur with others in the series. In fact, the necessity for overlap has proved to be relatively small and where it occurs the treatment of topics is consistent from one book to another.

It is wise to remember that no branch of science is more 'fundamental' than any other, so no suggestion has been made that the books need to be studied in a given order. Teachers will be free to use them in any sequence or combination which suits their own courses.

All the authors concerned with the series have felt keenly the inadequacy of purely descriptive biology in giving insight into the basis of science today. It has been necessary therefore for them to introduce some mathematics, physics and organic chemistry to which biology is so closely related. The names of chemical compounds are accompanied by their new names under the IUPAC rules and in The cell concept there is an introduction to the new uses which seem difficult at first but which are in fact logical and easy to follow once the principles have been grasped.

The diversity of life includes a wider range of examples of species than is strictly needed by a candidate for any one examination board but because of this the 
demands of almost all boards are met. This abundance of examples also enables the student to appreciate more fully the characteristics of phyla and the variations within them. The external characteristics of organisms are described in all cases except where knowledge of internal anatomy is required to understand life cycles.

The authors of The diversity of life have found in their own teaching a need to append to the study of species concise ecological notes. Accordingly, such notes are included in the book linked with the appropriate illustrations. The authors urge teachers and students to regard the illustrations as a guide to the study of the organisms and not a substitute for them. Whenever possible live specimens should be examined.

L. M. J. Kramer

General Editor 